\title{
Archaeobotanical Investigation of Charred and Desiccated Fruit Stones and Seeds from Late Holocene Contexts in Kassala and its Environs: Window to Past Ecology and Subsistence
}

\author{
Alemseged Beldados ${ }^{1}$
}

\begin{abstract}
With the aim of reconstructing the Late Holocene palaeoenvironment and vegetation history of Kassala and its environs, archaeobotanical investigation was conducted on charred and desiccated fruit stones and seeds. These botanical remains were recovered by dry screening from various contexts in three excavation squares. The excavations were conducted by the Italian Archaeological Expedition in East Sudan (IAEES) at the site of Mahal Teglinos, Kassala, northeast Sudan in the years 1991, 2013 and 2014. Identification and comparative study was conducted in the laboratories of Addis Ababa University and the Bioarchaeological Research Center of the National Museum of Oriental Art, Rome. A total of $1771(n=1771)$ charred and desiccated fruit stones and seeds are identified belonging mainly to five species: Adansonia digitata, Ziziphus spina-christi, Celtis integrifolia, Vigna unguiculata and Grewia bicolor. The botanical remains are dated to the early second millennium BC when the area was populated by several Gash Groups (along the Mereb river). The identification of the macrobotanical remains indicated that the site of Kassala and the Ethio-Eritrean and Sudanese low-lying border region was characterized by semi-arid and sub-humid tropical environmental conditions by the Late Holocene.
\end{abstract}

Keywords: fruit stones, seeds, semi-arid, Late Holocene, Eritrea-Sudanese border

\footnotetext{
${ }^{1}$ Assistant Professor, Department of Archeology and Heritage Management, Addis Ababa University
} 


\section{Introduction}

This paper presents comprehensive data on a range of charred and desiccated fruit stones $^{2}$ and seeds recovered from Archaeological contexts near Kassala, northeastern Sudan, along the Eritrea and Sudanese border. Most archaeological missions which are active in the region have the objective of understanding the Holocene culture history of Eastern Sudan and the Nile Valley, and they focus on the recovery and identification of edible cereals which were under cultivation and consumption in the region. There are, therefore, limited attempts reported so far that undertake archaeobotanical studies of fruit stones and seeds useful for reconstructing palaeoenvironment and vegetation history of the region. Previous reports from the region include the recovery of Celtis integrifolia and Ziziphus spina christi dominantly and less frequently Grewia renax (Magid 1989). This paper adds new archaeobotanical evidence of Adansonia digitata, commonly known as the baobab tree, and Grewia bicolor from the site of Mahal Teglinos, Kassala.

Non-carbonized fruit stones of Celtis integrifolia were identified from the sites of Khartoum Hospital and Garif town in a context dating to cal. 7410 \pm 100 BP (Arkel 1949) and later from the site of Esh Shaheinab (Magid 1989). Carbonized fruit stones of the same species were also recovered from the sites of Kadero I, and from Mesolithic sites in the Atbara area, Abu Darbien, Zakyab and Umm Direwiya. The Mesolithic sites along the Atbara region are dated to cal. $7700 \pm 140$ BP (Kryzyaniak 1978; Magid 1989).

From the site of Shaqadud cave carbonized and desiccated fruit stones of Ziziphus spina-christi were recovered in a context dated between 4200 and 3600 years BP (Magid 1984). Similarly, the two Esh Shaheinab sites, Islag and Nofalab, yielded charred and desiccated fruit stones of the same species. Ziziphus was also reported from the Mesolithic site of Abu Darbien (Magid 1989). From East Sudan, from Mahal Teglinos at Kassala 1 and 2, Ziziphus species were uncovered (Costantini et al. 1983). The only identification belonging to genus Grewia is a report on Grewia renax from the cave site of Shaqadud from similar layers in which the Celtis integrifolia samples were recovered (between 4200 and 3600 years BP).

Adansonia digitata is often viewed as a typical component of the African savanna. Biogeographical and genetic studies indicate that this species was endemic to West Africa and brought to eastern Africa and across the Indian Ocean

\footnotetext{
${ }^{2}$ A fruit stone also known as a drupe is a fruit with a large "stone" inside. The fruits are edible. The stone cannot be considered as seed as the seed is inside the stone.
} 
through human agency (Pock Tsy et al. 2009). Baobab is an important traditional food and medicinal plant in most places of Africa particularly in eastern and subSaharan Africa (Andrews 1952; Burkill 1997; Mabberley 2008). Since the dried fruit when still in the pod is light, easily storable and transportable, it is associated with modern mobile pastoralists (Blench 2007).

The other species which is identified for the first time from Kassla is cowpea, Vigna unguiculata. Cowpea is dominantly a savanna plant widely growing in the semi-arid and sub-humid areas of Central and West Africa as well as Asia. For most inhabitants of sub-Saharan Africa, cowpea is an important source of protein in their diet. The two probable areas for the domestication of cowpeas are northeastern and tropical West Africa (D'Andrea et al., 2007).

\section{The Study Area}

Kassala is located some 350 kilometers to the east of Khartoum. The center of the city of Kassala is found to the east of the Gash River. Taking into account the dry and semi desert environmental condition of the region, it is possible to assume that the river was an important attraction for the establishment of the city and prehistoric settlements in ancient times. To the west of Kassala, there is the Atbara River and the Butana grassland (Figure 1). The average elevation of the area is about $500 \mathrm{~m}$ a. s. 1.. The highest part of Kassala is the granite hill of Jebel Kassala which is $700 \mathrm{~m}$ a.s.l. (Sadr 1991; Beldados 2015).

With irrigation from the Gash and Atbara Rivers in Kassala and the surrounding areas cereals, fruits and vegetables are cultivated today. Some of the most commonly cultivated cereals, fruits and vegetables include sunflower (Helianthus annus), cowpea (Vigna unguiculata), sesame (Sesamum indicum), cotton (Gossypium barbadene), peanuts or ground nuts (Arachis hypogaea), chili pepper (genus Capsicum), onions (Allium cepa), okra (Abelmoschus esculentus), cluster bean (Cymopsis psoraloides), millet (either Pennisetum glacum or Eleusine coracana), sorghum (Sorghum spp.), chick pea (Cicer arientinum), broad bean (Vicia faba), orange (Citrus sinensis), bannana (Musa paradisiaca), watermelon (Citrullus lanatus), papaya (Carica papaya), and lemon (Citrus limon) (Beldados 2015).

Kassala and its environs are inhabited by various population groups who claim their descent separately. The major inhabitants of the area are the Beja (include the Beni Amir and the Hadendewiya), the Rashaida, the Halenga, Hawsa, Al-Habab, Shukriya and Halfawin. The Rashaida claim their descent across the Red Sea, on the Arabian Peninsula as migrants of a century and half ago. In terms of number, the Beja, who live both in Eastern Sudan and the western lowlands of Eritrea, constitute a majority. The Beni Amir pastoral communities, in particular, 
are known for their seasonal movements across current political boundaries of the region (Fattovich 1990; 1993; 1995; Beldados 2015).

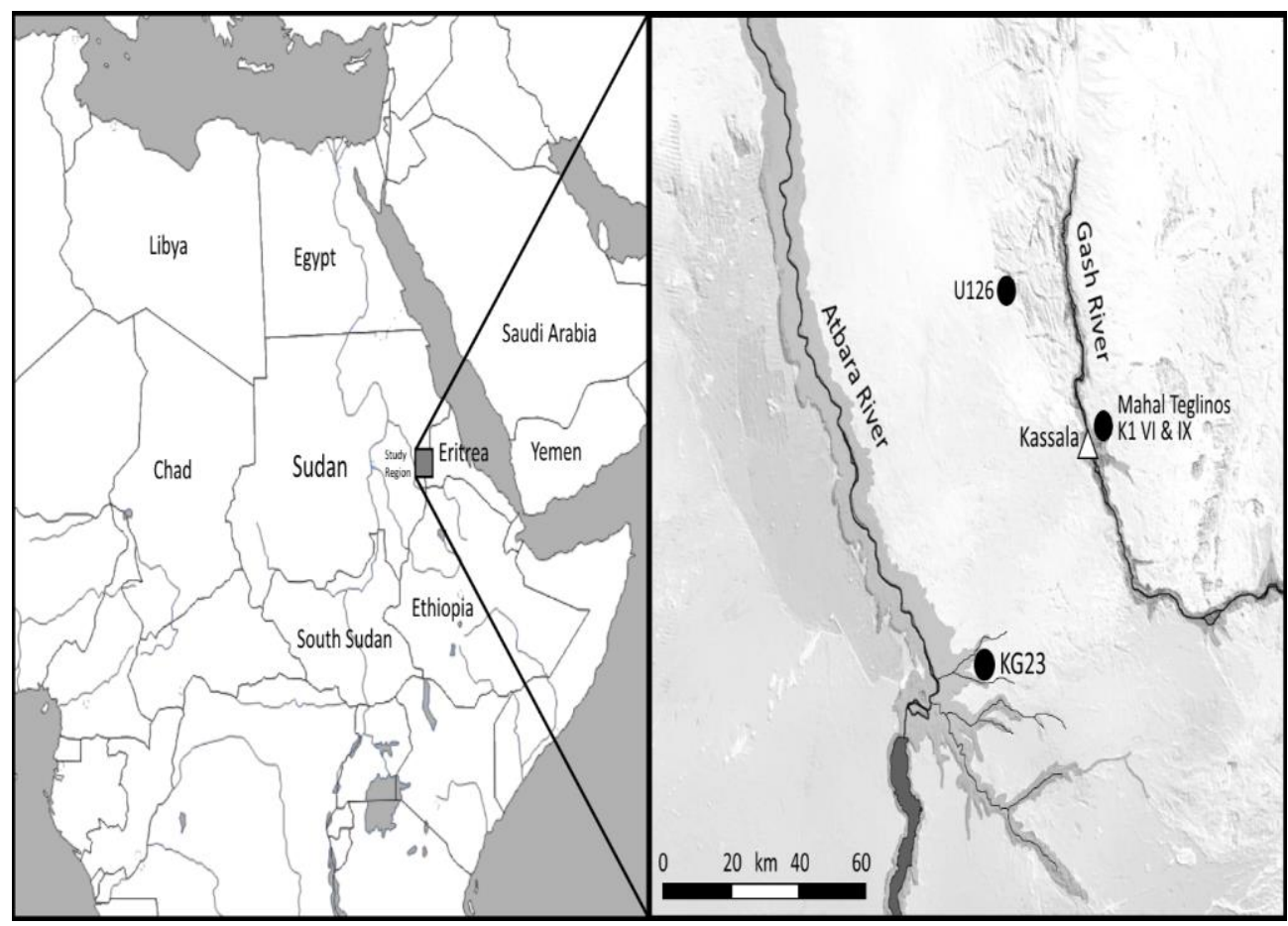

Figure 1. The study area: Kassala and its environs

\section{The Gash (Mereb) Delta Cultural Groups}

Decades of research on the study of the archaeology of the Gash Delta resulted in the classification of the cultural groups of the area into six major entities. These are outlined in Table number 1, and a brief description of these six major cultural groups is presented below. 
Table 1. Major cultural groups and their chronology

\begin{tabular}{|l|l|l|}
\hline No. & Cultural Groups & Chronology \\
\hline 1 & Amm Adam & Ca. 8th-7th millennia B.P. \\
\hline 2 & Malawiya & Ca. 7th-6th millennium B.P \\
\hline 3 & Butana & Ca. 6th-5th millennia B.P. \\
\hline 4 & Gash & Ca. 5th-4th millennia B.P. \\
\hline 5 & Jebel Mokram & Ca. 4th-3rd 2 nd millennia B.P. \\
\hline 6 & Hagiz & 2nd millennium B.P. to Early 1st millennium A.D. \\
\hline
\end{tabular}

\section{Amm Adam Group}

The Amm Adam Group flourished between about 8th-7th millennia B.P. and represents the oldest stage of the cultural sequence in the Gash Delta. This is, probably, the stage in which the process of peopling the delta started. The cultural tradition of Amm Adam can be paralleled with what is known as the Pre-Saroba site of the Kashm el-Girba area (KG14). Near Kassala, two sites with a distinct ceramic tradition that belongs to this stage were discovered. The data acquired from this period, however, is still insufficient (Fattovich 1989:483).

The sites of Amm Adam are identified north of the Gash Delta (three sites) and west of the Delta near Ukheiderat and Jebel Ofreik, where it is represented by a number of sites. All of these sites are situated on the flat alluvial plains of the Delta. What is typical of this tradition are the ceramics decorated in knobs. The sherds have also some elements that are similar to the Khartoum Horizon style, Central Sudan. However, this ceramic tradition is separate from the ceramic traditions of the Nile Valley (Fattovich and Piperno 1982, Manzo 2015).

Triangular and rectangular bands of knobs mostly along the rim and in a wavy line model, cord impressed horizontal or slant lines along the lips and rims, and rocker stamped wolf tooth style are some of the most common types of pottery decorative techniques and patterns that belong to the Amm Adam tradition (Beldados 2015). The knobs consist of holes closed with clay balls. The economy of the inhabitants was largely based on the utilization of aquatic resources. This is deciphered from barbed-bone harpoons collected from some of the sites and this is comparable to the Early Khartoum sites. In addition, faunal remains from the same site indicates the presence of wild grazing antelopes and aquatic animals like hippopotamus, fish, buffalo, warthog (ibid.). The Amm Adam sites are not dated using radiometric system. However, based on comparison with the Early Khartoum and Pre-Saroba sites, a date range between 8,000 and 6,000 years B.P. is suggested (Fattovich 1989: 484). 


\section{Malawiya Group}

The Malawiya Group marks the beginning of the evolutionary stage of the Atbai Ceramic Tradition which is termed the Saroba Stage. The Group was first observed in the Kashm el-Girba area. Almost all of the sites that belong to this Group are situated between the Atbara River and Shurab el-Gash (Marks and Fattovich 1989: 455-456). The ceramics of the Malawiya Group are often decorated in punching and rocker stamped wolf tooth motifs.

Most of the sites are identified in the steppe along an old river bed of the Gash. The sites have rendered no animal bone remains to comment on subsistent pattern and the paleo-ecology. However, large accumulations of Pila shells are reported which shows an environment with seasonal transgression of floods. Based on the evidence from Khashm el Girba, it is possible to deduce that the inhabitants of these sites were hunters/gatherers who were dependent partly on the available savanna and riverine vegetation and partly on the aquatic resources (Fattovich 1989: 486). The ceramics from the Malawiya Group can be comparable with the Khartoum Horizon style whereas, the motifs have no affinity with the cultural groups that had flourished along the Middle Nile. The dates provided for this Group are between 5th to 4th millennium B.C. based on comparison with Khashm el-Girba (Ibid.).

\section{Butana Group}

The Butana is a flat featureless plain extending from the Nile to the Abyssinian Plateau (Abbas et al., 1989:473). The Paleoenvironment of the Butana area, as briefly described above, was more of a savanna habitat as can be reconstructed from the faunal remains recovered from the sites. Wild animals' bones, fish, crocodile, hippopotamus, and an array of bovids of different sizes were documented (Ibid.). This site was first reported by Shiner (1971). The main sites of the Butana Groups are to be found in the Kashm el-Girba area. Near Kassala, from Jebel Tukulabab to Shurab el-Gash, twenty four sites were identified as belonging to the same tradition. The main characteristics of the pottery assemblages recovered from these sites is that the majority are of thread tempered. The Butana Group, the Gash Group and the Agordat Group are manifestations of the second evolutionary stage of 'the Atbai Ceramic tradition' known as the Kassala Phase. According to Fattovich (1989: 487), these are 'regional variants of the same basic tradition.'

\section{Gash (Mereb) Group}

The nucleus of the Gash Group people was Eastern Sudan. Adjacent to the Gash Delta, around 32 Gash group sites have been identified. The main site of these 
groups is Mahal Teglinos, near Kassala and has provided sherds that have affinities with the C-Group and Kerma. On the basis of social organization, sequence of cultural deposits and cultural changes observed within the Gash Group, Fattovich (1993) has suggested four distinct periods. These include; the proto-Gash Group (3000-2500 B.C.), Early Gash Phase (2500-2300 B.C.), Middle Gash Group (2300-1900 B.C.) Classic Gash Group (1900-1700 B.C.), Late Gash Group (17001500 B.C.) and Terminal Gash phase (1500-1400 B.C.).

At the time of the Proto-Gash Group, settlements were more permanent as can be deduced from the thick layer of cultural deposits at Mahal Teglinos. During this phase, the hunting of wild game seems to have been the main subsistence base of the people in the Gash Delta. At the time of the Early Gash phase, the Butana Group people moved eastwards and occupied the Shurab el Gash area, following the change of the course of the Gash River. This process probably facilitated the interaction of the Gash Group people with the Kerma. The contact between the two cultural groups might have resulted in reviving the Gash Group proper. This phase marked the shift from Butana to Gash cultural phase.

Since 2000 B.C. monolithic stelae were used as funerary markers, and one of the oldest burial stelae was recovered during this period. Fattovich (1993) considered the site of Mahal Teglinos (K1) as ceremonial based on the worship of the dead. The Gash Group's cultural influence was also seen at Eriba, further north towards the Red Sea Hills. The Subsistence pattern was based on both the utilization of wild species and on pastoralism. In terms of administrative structure, the Gash Group people were hierarchical. The recovered ceramic seals indicate that the inhabitants at Mahal Teglinos were organized as a chiefdom. There is evidence for cultural interactions with the C-Group and Kerma culture of the Middle Nile Valley region (Fattovich et al. 1984).

The Gash Group reached its maximum territorial stretch to the east, inhabiting most of the Eritreo-Sudanese border areas and to the north up to the Red Sea coast during the Classic Gash Group Phase. Comparable cultural manifestations, like that of the Gash Group, were observed at Agordat, Aqiq, and Erkowit. At the same period, the sphere of influence of the Shurab el Gash area increased by two more temporary settlements. The subsistence base of the Gash Group people during this phase was on animal husbandry and cultivation of crops. It was also during this time that the economic interaction between Nubia, the highlands of the Horn of Africa, and Egypt became strong. The 'Circuit' of trade might also have involved Somalia and Southern Arabia. The midway role for this trade contact between Egypt and the highlands of the Horn of Africa was probably taken by Mahal Teglinos (Fattovich 1993). 
The Terminal Gash is the last phase of the Gash Group cultural tradition, marked by the absence of an archaeological record. However, on the basis of the little evidence from Mahal Teglinos, it is possible to see the presence of interaction with peoples of the Pan-Grave culture and that of the C-Group from II/b phase. A reduction in settlement areas and the decline of trade with the highlands of the Horn and Egypt are probably reasons for the absence of evidence. This decline, on the other hand, might have facilitated the expansion and control of the Gash Delta by the people belonging to the Pan-Grave Culture (Fattovich et al., 1984; Fattovich 1993).

\section{Jebel Mokram Group}

The archaeological evidence revealed that the Jebel Mokram Group had inhabited southern Atbai from about the mid- $2^{\text {nd }}$ millennium B.C. to the mid- $1^{\text {st }}$ millennium A.D. In terms of chronology, this Group is further divided into Mokram (Ca. mid 2nd millennium B.C. to Ca. early 1st millennium B.C.) and the Late Mokram Group (Ca. early to mid-1st millennium B.C.). After the late Kassala Phase (Ca. 1500-750 B.C.), the Gash Group material culture is replaced by the Mokram Group. The ceramics of the Mokram Group have affinity with that of the PanGrave culture (Sadr 1991: 47-48). Together with the Mokram Group, a new stone tool technology also appeared in the record, including distinctive "T"-shaped polished axes and stone bracelets. Sadr (1988:90 see also 1991:45) commented that these new stone tool technologies were made of 'imported Porphyry' (reddish purple stone containing large sized crystals, dominantly feldspar). Highly refined polished axes with metal prototypes and stone bracelets are also common in the Barka Valley of Agordat as can be observed in the collections of Arkell (1954) housed in the National Museum of Khartoum (Beldados 2006: 49). In comparison with the Gash Group, the subsistence pattern at this stage was not changed that much. There is evidence for the presence of cattle (Sadr 1991: 48), while the archaeobotanical data has also revealed that sorghum and millet were cultivated at the time (Costantini et al. 1983:17-19). In addition, there was direct evidence for sorghum and millet in the Teka Phase (Ca. 750 B.C. to 350 A.D.), contemporaneous with the Aksumite Empire.

\section{The Hagiz Group: Contemporaries of the Damat D'MT}

The Hagiz Group marks the final phase of the 'Atbai Ceramic Tradition'. This Group was first categorized as the Jebel Teka Group by Fattovich and Pipperno (1986). Along the Gash Delta around seventeen sites were identified belonging to the same Group in Jebel Mokram and Shurab el-Gash areas. During the Teka Phase, the ceramics was again similar with the Mokram. The only exception at this 
time is that mineral tempering is substituted by a mix with fiber tempering (Fattovich 1989: 497). The technique of using fiber as temper material is also observable among the ceramics of the Agordat collection (Beldados 2006: 58-59). The first pastoralists of the Southern Atbai, the Hagiz Group, were dominant at this stage. The main diagnostic elements of the Hagiz Group ceramics are crudeness and fiber tempering. Like that of the Gash Group, they decorated their pottery using rim band motifs and scraping. Pre-Aksumite types of pottery fragments were also observed in the sites belonging to the Hagiz Group, demonstrating their contemporaraneity (Sadr 1991:49-50).

\section{Materials and Methods}

The macrobotanical remains presented here were recovered from excavations over three field seasons at Mahal Teglinos (K1), which is a major artifact bearing site in Kassala. The excavations were conducted in the years 1991, 2013 and 2014 by the IAEES. The first excavation was K1 V, a $2 \times 3 \mathrm{~m}$ trench undertaken at 5026.57 North and 036025.72 East (Beldados 2015). This spot was excavated down to a depth of $1 \mathrm{~m}$ and is culturally affiliated with the Jebel Mokram (early second millennium BC to early first millennium BC) and the later phase of Gash Group (early second millennium $\mathrm{BC}$ ). The purpose of this excavation was to reconstruct the cultural chronology of the mid and late Holocene inhabitants of the area. All macrobotanical remains were recovered by dry sieving using a $1 \mathrm{~mm}$ size mesh and were kept in 50 test tubes. The collections were identified and analyzed, aided by reference to the comparative collections in the Bio-archaeological laboratory of the National Museum of Oriental Art, Rome.

The charred and desiccated fruit stones recovered from various unit levels of the 2013 and 2014 field seasons derive from excavations undertaken in the same site of Mahal Teglinos, K1, Trench IX (15'26'31.55"N 36²5'52.46"E) (Manzo 2014, 2015). The 2014 excavation was a continuation of what was started in 2013. K1 IX is a 4x6 m unit in the western part of Mahal Teglinos, near the granitic hill of Jebel Taka. The excavation continued down to $0.80 \mathrm{~m}$ depth. The aim of the excavation unit was to explore previously uninvestigated Gash Group settlement.

The top layers of the excavation have characteristic features belonging to the Jebel Mokram Group (early second millennium BC-early first millennium BC). The subsequent layers are associated with the later phase of the Gash Group culture dating to the early second millennium BC. The same assertion was confirmed by a radiocarbon date on charcoal of 1960-1760 cal. BC (Beta-380246: 3560 \pm 30 BP) (Manzo 2015). Soil samples from each unit levels were dry sieved using a $1 \mathrm{~mm}$ mesh. Classification and analysis of the botanical remains was 
conducted at the laboratory of the Department of Archaeology and Heritage Management, Addis Ababa University.

\section{Result: Description of the Recovered Plant Remains (Type 1, 2, 3)}

From the three excavations, a total of 1771 carbonized and desiccated fruit stones and seeds were recovered: 685 from 1991, 144 from 2013 and 1018 from 2014. Four different species are identified in the K1 VI excavation units undertaken in 1991. These include 24 carbonized and 184 desiccated fruit stones of Celtis integrifolia, 162 carbonized and 20 desiccated fruit stones of Ziziphus spinachristi, 177 carbonized grains of Vigna unguiculata and 36 carbonized grains of Grewia bicolor Juss. (Table 2). Samples from the 2013 field seasons provided a total of 68 carbonized remains; 66 carbonized fruit stones of Adansonia digitata and 2 fragments belonging to Ziziphus spina christi (Table 3). Investigation of the 2014 field season provided three different species (Table 4); 486 carbonized and 158 desiccated macrobotanical remains of Adansonia digitata, 297 carbonized and 50 desiccated species belonging to Ziziphus spina Christi, and 7 carbonized and 20 desiccated remains of Celtis integrifolia.

Table 2. Carbonized and desiccated fruit stones from 1991 excavation

\begin{tabular}{|c|c|c|c|c|c|c|c|}
\hline Provenance & Identification & Carbonize & & Desiccated & & Total & Cultural \\
\hline K1V & & Complete & Fragments & Complete & Fragments & & \\
\hline & Celtis integrifolia & 19 & 5 & 65 & 119 & 208 & $\begin{array}{l}\text { Gash } \\
\text { Group }\end{array}$ \\
\hline & $\begin{array}{l}\text { Grewia bicolor } \\
\text { Juss }\end{array}$ & 36 & - & & & 36 & " \\
\hline & $\begin{array}{l}\text { Vigna } \\
\text { unguiculata }\end{array}$ & 14 & 163 & & & 177 & " \\
\hline & Zizphus sp. & 69 & 93 & 4 & 16 & 182 & " \\
\hline & Unidentifiable & - & 82 & & & 82 & $"$ \\
\hline & Total & 184 & 457 & 23 & 21 & 685 & $"$ \\
\hline
\end{tabular}

Table 3. Carbonized fruit stones from 2013 excavation

\begin{tabular}{|l|l|l|l|l|l|}
\hline Provenance & Identification & \multicolumn{2}{|l|}{ Carbonized } & Total & $\begin{array}{l}\text { Cultural } \\
\text { Affiliation }\end{array}$ \\
\hline \multirow{4}{*}{ K1 IX } & & Complete & Fragments & & \\
\cline { 2 - 6 } & Adansonia digitata & 44 & 22 & 66 & $\begin{array}{l}\text { Jebel } \\
\text { Mokram }\end{array}$ \\
\cline { 2 - 7 } & Ziziphus $s p$. & - & 2 & 2 & $"$ \\
\cline { 2 - 7 } & Total & 44 & 24 & 68 & $"$ \\
\hline
\end{tabular}


Table 4. Carbonized fruit stones from 2014 excavation

\begin{tabular}{|l|l|l|l|l|l|l|l|}
\hline Provenance & Identification & \multicolumn{2}{|l|}{ Carbonized } & \multicolumn{2}{l|}{ Desiccated } & Total & $\begin{array}{l}\text { Cultural } \\
\text { Affliation }\end{array}$ \\
\hline \multirow{3}{*}{ K1 IX } & & Complete & Fragments & Complete & Fragments & & \\
\cline { 2 - 9 } & $\begin{array}{l}\text { Adansonia } \\
\text { digitata }\end{array}$ & 326 & 220 & 61 & 37 & 644 & $\begin{array}{l}\text { Gash } \\
\text { Group }\end{array}$ \\
\cline { 2 - 9 } & Ziziphus sp. & 144 & 153 & 23 & 27 & 347 & $"$ \\
\cline { 2 - 9 } & $\begin{array}{l}\text { Celtis } \\
\text { integrifolia }\end{array}$ & 2 & 5 & 11 & 9 & 27 & $"$ \\
\hline & Total & 481 & 322 & 86 & 129 & 1018 & \\
\hline
\end{tabular}

\section{Type 1: Adansonia Digitata}

The largest share of the recovered botanical remains belongs to A. digitata. As indicated in Table 4, from the 2013 and 2014 excavations, a total of 1084 carbonized and desiccated fruit stones were retrieved. This species accounts for $61.2 \%$ of the botanical remains. The seed of A. digitata has a multiple-layer seed coat with thin outer and inner layers. It often loses its outer and inner layers. The middle layer, on the other hand, is thick and has striations. The size of the charred seed is $0.8-1.0 \mathrm{~cm}$ on average, which is comparable with the size of the seed for the modern plant. The species has a very large cylindrical pod which can grow up to $35 \mathrm{~cm}$ in length. Inside this fruit, there are smaller seeds with a diameter of 0.8 $1.0 \mathrm{cms}$ (figure 2). The color of the seeds range between dark brown and reddish black (Heuze et al. 2016).

The modern plant is native to West Africa and the Swahili coast. It is widely distributed in the drier parts of tropical Africa, from Mauritania in the northwest to Sudan in the northeast. Its presence in Eastern Sudan during the second millennium BC might be a result of anthropogenic dispersal (Ibid.). 


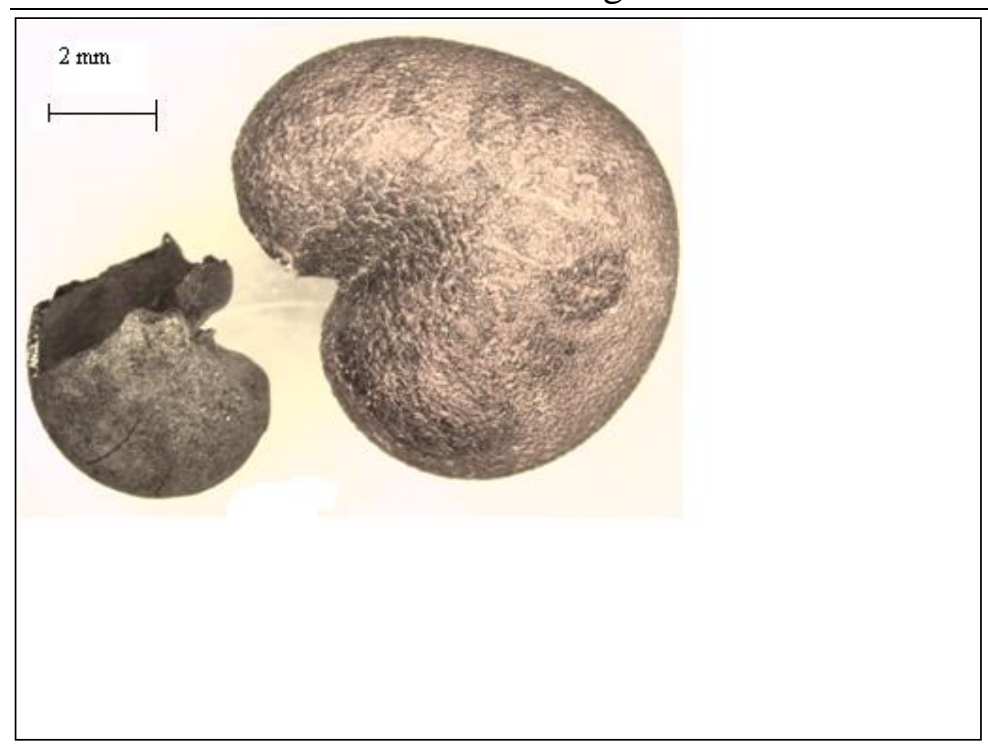

Figure 2. Adansonia digitata, carbonized remain (left), modern seed (right)

\section{Type 2: Ziziphus Spina-christi}

This species constitutes the second largest group among the recovered carbonized fruit stones and is identified from all three field seasons. A total of 531 remains are counted and this accounts for $29.9 \%$ of the total. The size of the charred and desiccated fruit stones is proportional, $0.7-1.4 \mathrm{~cm}$. The most likely modern analogue for this morphotype is Ziziphus spina [Christi] (L.) Willd with the fruit having a size of $0.8-1.4 \mathrm{~cm}$. It has a single rough cover with two seeds inside them (figure 3). This plant is widely distributed in drier tropical Africa from West Africa to northeast Africa, including Ethiopia (Beldados 2015).

The modern fruit is spherical in shape, including the flesh it can grow to 2.5$3.5 \mathrm{~cm}$ in diameter. It has a sweet edible skin which can be eaten fresh or dried. People most often prefer eating them in the interval time, while the fruit ripens. Fruits ripen in autumn-winter and are harvested for at least two months. In the drier tropics, the fruits can be left to dry and are later consumed as dates (Lyle 2006). 


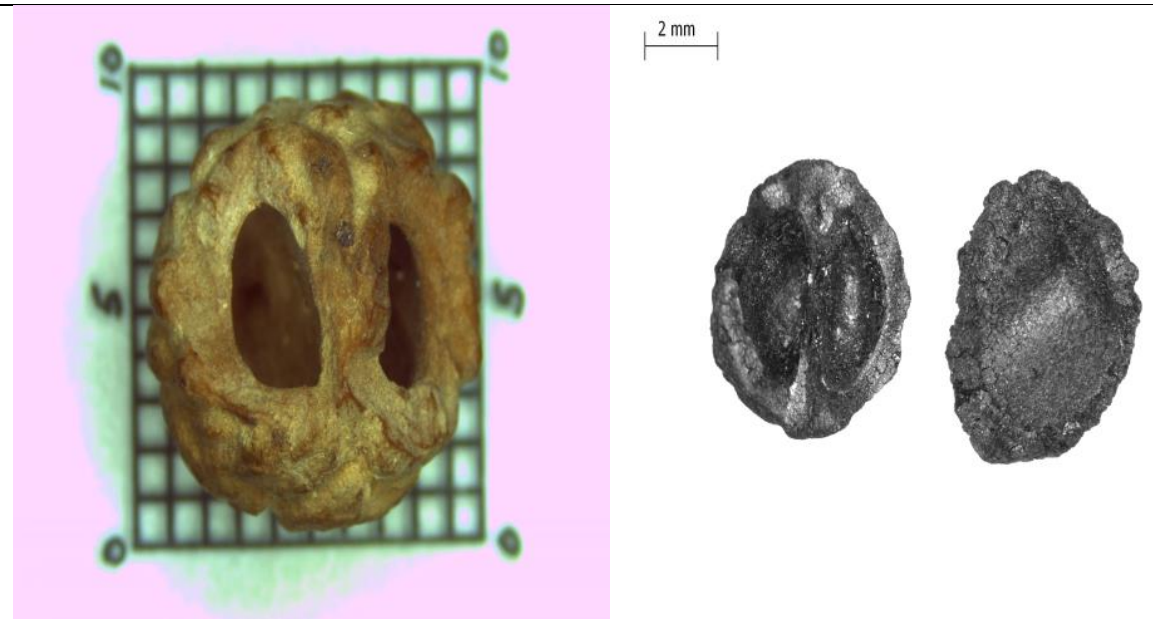

Figure 3. Ziziphus spina Christi, modern seed (left), carbonized remains (right)

\section{Type 3: Celtis Integrifolia}

A total of 235 carbonized and desiccated fruit stones belonging to this species were counted from the 1991 and 2014 field seasons. This amount accounts for 13.26\%. Unlike the other fruit stones, which are mainly charred, the fruits of Celtis integrifolia are dominantly recovered in desiccated form. The most comparable modern types of these botanical remains are the Celtis integrifolia species that grows in the savanna and Sahel region of tropical Africa (figure 4). Guinko (1984: 256) has already categorized them as typical Sudanese species. The fruit of the modern plant has a diameter of $0.5-1.0 \mathrm{~cm}$. Most of the archaeological fruits are measured $0.6-0.8 \mathrm{~cm}$.

The fruit of the modern plant is small, spherical and fleshy. Surrounding the stone, there is a thin yellowish skin which is sweet. They are orange brown when immature and turn purple black when ready for consumption (Lyle 2006). They ripen during autumn but can be left on the tree until winter, for later use. 


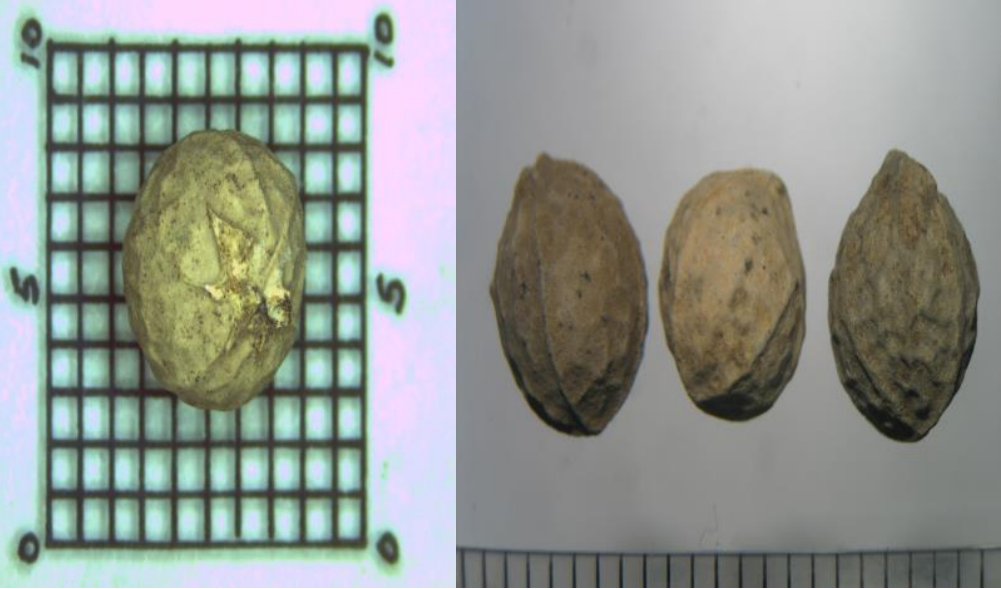

Figure 4. Celtis integrifolia Lam. modern specimen (left) and desiccated fruit stones (right)

\section{Type 4: Vigna Unguiculata}

This species was only recovered from the 1991 excavation (K1 VI). Out of the total, 177 botanical remains were identified, constituting $9.99 \%$. The size of the seeds is 0.6 to $1.2 \mathrm{~cm}$ and it has a kidney-like shape (figure 5). Seeds of the modern cultivated variety of the same plant flourish in the Sahelian zone of tropical Africa from West Africa all the way to northeast Africa (D'Andrea 2007). The seeds often break down into two cotyledons. Inside the cover, the seeds are naturally made to be divided into two equal parts.

The seeds of the modern plant have different colors; brown, white, green, grey, red, and black. The seeds are contained inside the pods of the plant and each pod contains between 8 and 15 seeds. The pods occur in cylindrical and curved shapes. The seed coats are either smooth or wrinkled (Timko et al. 2007). 




Figure 5. Vigna unguiculata, modern comparative

\section{Type 5: Grewia Bicolor Juss.}

The smallest proportion of all the identified species belong to Grewia bicolor Juss. Similar to the Vigna unguiculata, it is only recovered from excavation K1 VI. A total of 36 carbonized remains of this plant were identified, $2.03 \%$ of the aggregated total. The size of the fruit is 0.5 to $0.7 \mathrm{cms}$ (see figure 6). The seeds identified are comparable with Grewia spp. based on comparisons in Cappers et al. (2009: 905: photo number 9233). This modern plant dominantly grows in low and mid altitude of dry savanna from West Africa to the margins of the highlands of Ethiopia. This zone is categorized as a native zone for the species. It also grows in southern Africa, the Middle East and India (Orwa et al., 2009).

The fruit is single or double lobed, and each lobe has a diameter of about 0.6 $\mathrm{cm}$. Fruits are circular, fleshy and edible. They are red-brown and orange while growing and change their color to purple or red when ripe. They are sweet when ripe. The tree grows very slowly but provides abundant fruit during rainy seasons (Ibid). 


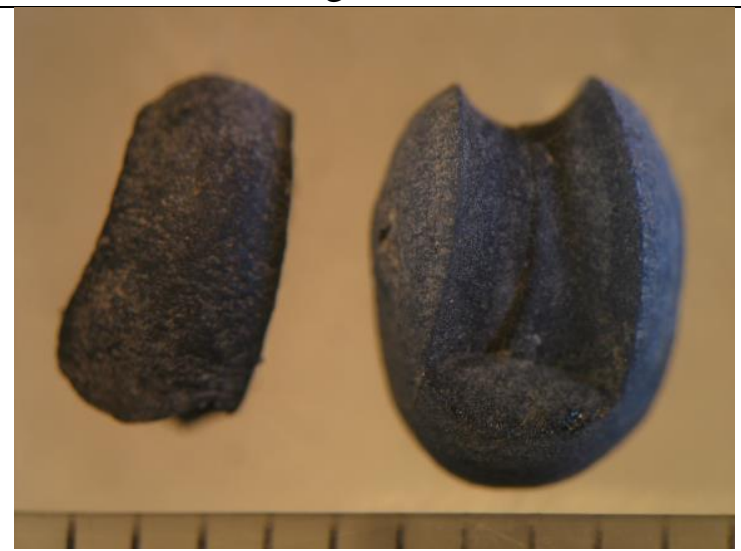

Figure 6. Grewia bicolor Juss., Carbonized remain

\section{Discussion and Conclusion}

The total amount recovered from Kassala in aggregate $(n=1771)$ (Table-5) is more than the previous archaeobotanical collections from Neolithic sites of Khartoum Hospital, Garif town, Esh Shaheinab and Kadero I. The Mesolithic sites in Atbara area; Abu Darbien, Zakyab and Umm Direwiya also provided less carbonized and desiccated seeds and fruit stones in comparison with Kassala. Adansonia digitata, baobab tree is classified under the Malvaceae family. The tree can grow as high as $25 \mathrm{~m}$ and the trunk can reach a diameter of 10-14 m. The branches are thick and wide. The bark is smooth with color ranging from reddish brown to grey. Flowers are longer with a maximum length of up to $12 \mathrm{~cm}$. It mainly grows in the hot and dry savanna areas of sub-Saharan Africa. The plant is very effective in preventing water loss and can flourish in sandy soils. In East Africa, the trees grow in the shrub lands and coastal areas. Adansonia digitata is a traditional food plant in East and sub-Saharan Africa. It has a rich medicinal and nutritional value (Andrews 1952; Mabberley 2008). This is probably why it is recovered from a settlement site. 
Table 5. Aggregate of the identified fruit stones

\begin{tabular}{|l|l|l|l|l|l|}
\hline Identified species & 1991 & 2013 & 2014 & Total & $\%$ \\
\hline Adansonia digitata & - & 66 & 644 & 1084 & 61.2 \\
\hline Ziziphus spina christi & 182 & 2 & 347 & 531 & 29.9 \\
\hline Celtis integrifolia & 208 & - & 27 & 235 & 13.2 \\
\hline Vigna unguiculata & 177 & - & - & 177 & 9.9 \\
\hline Grewia bicolor Juss & 36 & - & - & 36 & 2.0 \\
\hline Unidentifiable & 82 & & & 82 & 4.6 \\
\hline
\end{tabular}

Baobab is an essential tree in most parts of the African savanna. According to biogeographical and genetic studies, this species was indigenous to West Africa and brought to eastern Africa by movement of pastoralists (Pock Tsy et al. 2009). The charred seeds of Adansonia digitata L. recovered from Kassala (Late Gash Group context) indicate one of the earliest archaeobotanical records for Sudan and northeast Africa. These finds suggest that this tree had already been transferred from west to east across the savanna by the early second millennium BC. However, more archaeobotanical study is needed to establish this suggestion.

Ziziphus sp. grows along the Nile banks and low lying plains. Ziziphus spinachristi in particular has a wide phyto-geographical distribution throughout the Sahara and the Sahel, from Senegal to the Sudan and to Arabia. The leaves of Ziziphus spina-christi (L.) can grow as long as $6 \mathrm{~cm}$ and are consumed by sheep and goats. According to ethnographic studies on human-plant use, the wood is exploited as an important source of fire and charcoal. Branches and leaves of the plant also have medicinal value to treat injuries and body part twists (El Amin 1990; Beldados 2015). It is a multi purposed tree and this can be a reason to find the botanical remains of the plant from an archaeological context. The earliest archaeobotanical evidence of Ziziphus spina-christi is recovered from the early Khartoum sites in Central Sudan dating to 9000-6000 years B.P. Several carbonized fruit stones of Ziziphus sp. were identified at Abu Darbien $(7860 \pm 190$ BP), Shaqadud cave $(3615 \pm 88-4123 \pm 86 \mathrm{BP})$ and El Shaheinab site (Islang and Nofalab, n.d.) (Majid 1989). The Kassala evidence together with previous finds from the same region suggests that this plant was available for human use from the Early to Late Holocene.

Celtis integrifolia is a large tree belonging to the Ulmaceae family. This species can grow as high as $25 \mathrm{~m}$. It has a unique trunk that could have a thickness of $1.5 \mathrm{~m}$. The roots have often a swollen shape. The bark of the tree has a smooth surface and is grey in color. Leaves are green in color and oval in shape. Celtis trees flower from February to April. This plant is common in tropical climatic 
settings, between 3 to 16 degrees north of the equator. It is widely available from Senegal to East Africa. Outside of Africa, it grows in the Arabian Peninsula. Celtis requires an annual rainfall of between 500 and $700 \mathrm{~mm}$. The leaves can be used in soups. The younger leaves and the fresh fruits are eaten as a salad (Maydell 1990; Beldados 2015).

The earliest evidence for the presence of Celtis goes back to $7700 \pm 140$ BP. It was recovered from the Mesolithic sites in the Atbara area, Abu Darbien, Zakyab and Umm Direwiya (Magid 1989). The report from the Mesolithic sites and the recovery of the same species from Late Holocene cultural contexts at Kassala suggest that Celtis integrifolia is among the more important species for regional inhabitants far before the advent of settled agriculture. According to ethnographic observations, shepherds and children currently consume the flesh of the fruit (Beldados 2015) and this might also be the same in pre-historic time. Its edible nature could also explain the reason for occurrence in archaeological sites.

Cowpea, Vigna unguiculata, is dominantly a savanna crop widely growing in the semi-arid and sub-humid areas of Africa and Asia. It is a leguminous plant, and for most inhabitants of sub-Saharan Africa, is an important source of protein in their diet. The cotyledons alone possess about $22-27 \%$ protein. The leaves of this plant are an important source of vitamin C. The plant is consumed by humans by roasting, boiling and after grinding into flour. Parts of the plant are used for medicinal purposes and in the production of dyes. It is also used as a fodder for livestock. Cowpea can adapt well in marginal environments unsuitable for the growth of other plants. In West and Central Africa, cowpea is a reliable source of food in times of drought. It is often intercropped with pearl millet and sorghum. There is an assumption that humans first gather wild cowpea to use it as an animal fodder (D'Andrea et al., 2007).

Based on the absence of the wild form outside of Africa, it is concluded that this plant was domesticated in Africa. The two probable areas for the domestication of cowpeas are northeast Africa and tropical West Africa. In India, cowpea was recovered from an archaeological context dating back to 1700-1500 BC. The date from West Africa is earlier, 1830-1595 BC based on AMS dating (D'Andrea et al., 2007). The closeness in time range may indicate an early dispersal to the Indian Sub-continent (Coulibally et al., 2002; D'Andrea et al., 2007). According to ethno-archaeological observations conducted at Kassala, cowpea is still cultivated by the inhabitants of the area (Beldados 2015). The evidence from Kassala suggests that the tradition of utilizing this plant could probably go as far back as early second millennium BC. Radiocarbon date on associated charcoal provided 1960-1760 cal. BC (Beta-380246: 3560 \pm 30 BP). 
Direct AMS dates from the Vigna samples are, however, important to determine the exact age.

Grewia bicolor is a shrub or a tree with in the Tiliaceae family. The bicolor Juss variety can grow as tall as 9-14 meters. The bark is grey and sometimes yellow-brown. The leaves could range between 1 to $8 \mathrm{~cm}$ in length and have dark green upper side and white or grey blue, hairless back side. At the time of extreme heat during the dry season, the leaves bend downwards. It produces small, yellow and shinning flowers which has $0.8 \mathrm{~cm}$ long sepals. The plant gives flowers and fruits during rainy season (Maydell 1990: 291).

Grewia bicolor Juss. grows in semiarid and sub humid tropical Africa and India. It has a special adaptation to calcareous soils. It also grows along river banks with sandy soils and on stony escarpments. It often grows in Sahelian bushlands. An average annual rainfall of $200-800 \mathrm{~mm}$ is sufficient for its complete life cycle and the biophysical limits of its distribution are 800-2000 m a.s.l (Orwa et al., 2009). The fruits of Grewia bicolor are edible. In Niger, it is used to prepare a local drink called 'madi' in Hausa language. It is a good source of food for varieties of birds. The fruits and leaves are also consumed by cattle. The nutritional value of the leaves is good. The wood is used in making walking sticks, bowls, tool handles and it is a common fire wood (Maydell 1990; Beldados 2015).

Grewia renax has been previously reported from Shaqadud Cave dating 4200 and 3600 years BP. Taking into account the Kassala remains, it is possible to suggest that the plant was present in the archaeological record of the region beginning from the Mid-Holocene.

Kassala and the adjacent environs of Eritrea and Ethiopia are low lying areas characterized by similar geographical settings (Sadr 1989; 1991, Beldados 2015). The entire region is currently inhabited by settled agriculturalists on both sides of the Gash River and mobile pastoralists such as the Beni Amir Bejas. The Beja pastoralists cross the current border demarcations in search of water and pasture. Along the banks of the Gash River, farmers currently cultivate a wide variety of cereals, vegetables and fruits. Some of the cereals (wild and domestic sorghum, millets) and fruits (Ziziphus sp., Vigna sp.) which are cultivated today were present in the archaeological record since the mid-Holocene. Archaeobotanical studies indicate that there is a continuation of plant cultivation and utilization on selected species which are best adapted to semi-arid and sub-humid tropical environments for the past 6,000 years (Beldados 2015). The charred and desiccated fruit stones and seeds discussed in this paper also confirm such environmental preference (see table 6 below). 
Alemseged Beldados

Table 6. Phyto-geography of the identified plants in broad
cultural/environmental periods
\begin{tabular}{|l|l|l|l|}
\hline No. & Identified plants & Environmental preference & $\begin{array}{l}\text { Period (based on } \\
\text { evidence from various } \\
\text { sites) }\end{array}$ \\
\hline 1 & Adansonia digitata & $\begin{array}{l}\text { Hot and dry Savanna areas of } \\
\text { sub-Saharan Africa }\end{array}$ & Early to Late Holocene \\
\hline 2 & Celtis integrifolia & $\begin{array}{l}\text { Hot and dry Savanna areas of } \\
\text { sub-Saharan Africa }\end{array}$ & Early to Late Holocene \\
\hline 4 & Vigna unguiculata & $\begin{array}{l}\text { Semi-arid and sub humid areas } \\
\text { christi } \quad \text { Spina }\end{array}$ & $\begin{array}{l}\text { Semi-arid Sahara and Sahel } \\
\text { Mid-late Holocene }\end{array}$ \\
\hline 5 & Grewia bicolor Juss. & $\begin{array}{l}\text { Semi-arid and sub humid to late Holocene } \\
\text { tropical Africa }\end{array}$ & Mid-late Holocene \\
\hline
\end{tabular}

According to the above table on Phyto-geography of the identified plants in broad cultural/environmental periods, the environmental preference of the identified plants range from semi-arid and sub humid to hot and dry. These plants grow in Sahelian and Sahara zone of the tropics. The evidence from Kassala and other sites suggested continuous presence of the plants from Early to Late Holocene in the case of Adansonia digitata, Celtis integrifolia and Ziziphus spina Christi. On the other hand, Vigna Unguiculata and Grewia bicolor Juss appear in the archaeological evidence starting from the Mid-Holocene.

\section{Acknowledgements}

The author is grateful for Andrea Manzo for giving access for the study of the botanical remains and Catherine D'Andrea for proof reading and constructive comments. The identification process was further enriched by discussions with Dorian Fuller. The microscopic image of Adansonia digitata was taken in the archaeobotanical laboratory of the University College London. The Bioarchaeological Research Center of the National Museum of Oriental Art Rome provided space for the study of the 1991 collections. 


\section{References}

Abbas, S.A. Muhhamed and Jager, Susan E. 1989. "The early ceramic of the Eastern Butana (Sudan)". In Lech Krzyzaniak and Michal Kobusiewicz, editors. Late Prehistory of the Nile Basin and the Sahara. Poznan Archaeological Museum .Poland: Poznan.

Andrews, F.W. 1952. The flowering plants of the Anglo-Egyptian Sudan (Volume II Sterculiacea-Dipsacaceae). Arbroath: T. Buncle \& co. Ltd.

Arkell, A. J. 1949. Early Khartoum. Oxford: University Press.

Beldados, A. 2006. The Agordat Material, Eritrea and its Implication for Early Food Production and Regional Contact (M.A Thesis). Norway: University of Bergen, Institute of Archaeology.

Beldados, A. 2015. Paleoethnobotanical study of ancient food crops and the Environmental context in North East Africa, 6000 BC-200/300 AD. Cambridge Monographs in African Archaeology 88. BAR International series 2706. Oxford: Archaeopress.

Blench, R. 2007. "The intertwined history of the silk-cotton and baobab". In Cappers, R. editor. Fields of change: progress in African archaeobotany. Groningen: Barkhuis \& Groningen University Library.

Burkill, HM. 1997. The useful plants of West Tropical Africa, Families E-I. Volume 2 ( $2^{\text {nd }}$ ed.). London: Royal Botanic Gardens.

Cappers, R.T.J, Neef, R. and Bekker, R.M. 2009. Digital Atlas of Economic Plants $2 b$. Groningen: drukkkerij Tienkamp.

Costantini, L., Fattovich, L., Piperno, M., and Sadr, K. 1983. "Gash Delta Archaeological Project: 1982 field season", Nyame Akuma: A Newsletter of African Archaeology, 23: 17-19.

Coulibaly, S., R.S. Pasquet, R. Papa and P. Gepts. 2002. "AFLP Analysis of the Phenetic Organization and Genetic Diversity of Vigna unguiculata L. Walp. Revels Extensive Gene Flow Between Wild and Domesticated Types." Theoretical and Applied Genetics, 104: 147-173.

D'Andrea, C.A., Kahlheber, L.A., Logan, L.A., Watson, J.D. 2007. "Early domesticated cowpea (Vigna unguiculata) from Central Ghana.", Antiquity 81: 686-698.

El Amin, H. Mohammed. 1990. Trees and Shrubs of the Sudan. England: Biddles Ltd Guildford and King's Lynn.

Fattovich, R, Marks, E.A. and Ali, M.A. 1984. "The Archaeology of the Eastern Sahel, Sudan: Preliminary results". African Archaeological Review, 2: 173188.

Fattovich, R. and Pipperno, M. 1986. "Archaeological Researches in the Gash Delta, Kassala Province (1980-81 Field Seasons)". In Krause, M., editor. 
Proceedings of the symposium of the International Society of Nubian Studies.

Mainz: Heidelberg.

Fattovich, R. 1989. "The Later Prehistory of the Gash Delta (Eastern Sudan)" In Lech Krzyzaniak and Michal Kobusiewicz, editors. Late Prehistory of the Nile Basin and the Sahara, Poznan Archaeological Museum. Poland: Poznan. Fattovich, R. 1993. "The Gash group of the Eastern Sudan: an outline." In L. Krzyzaniak, M. Kobusiewicz and John Alexander, editors. Environmental Change and Human Culture in the Nile basin and Northern Africa until the Second Millennium BC. Poland: Poznan.

Fattovich, R. 1995. "The Gash Group: A complex society in the lowlands to the east of the Nile." In Actes de la VIIIe Conférence Internationale des Études Nubiennes I: Cahier de Recherche de l'Institut de Papyrologie et d'Égyptologie de Lille 17.1: 191-200.

Heuze, V., Tran, G., Archimede, H., Bastianelli, D. 2016. African baobab (Adansonia digitata). Feedipedia, a programme by INRA, CIRAD, AFZ and FAO. Retrieved from: https://www.feedipedia.org/node.

Krzyzaniak, L. 1978. "New Light on Early Food Production in Central Sudan." Journal of African History, 19: 159-172.

Lyle, Susanna. 2006. Fruit and Nuts: A comprehensive guide to the cultivation, uses and health benefits of over 300 food-producing plants. North America: Timber Press Inc..

Mabberley, DJ. 2008. A portable dictionary of plants, their classification and uses. ( $3^{\text {rd }}$ ed.). Cambridge: Cambridge University Press.

Magid, A. 1984. "Macrobotanical Remains from Shaqadud: Interim Note." Nyama Akuma, 24: 25-27.

Majid, A.A. 1989. "Exploitation of plants in the Eastern Sahel (Sudan), 5,0002,000 B.C." In: Lech Krzyzaniak, L, Kobusiewicz, M., editors. Late Prehistory of the Nile Basin and the Sahara. Poznan: Poznan Museum.

Manzo, A. 2014. "Preliminary Report of the 2013 Field Season of the Italian Archaeological Expedition to the Eastern Sudan of the Università degli Studi di Napoli "L'Orientale"."Newsletter di Archeologia CISA 5:375-412.

Manzo, A. 2015. "Preliminary Report of the 2014 Field Season of the Italian Archaeological Expedition to the Eastern Sudan of the Università degli Studi di Napoli "L'Orientale", Newsletter di Archeologia CISA 6:231-240.

Maydell, V. Hans-Jurgen. 1990. Trees and Shrubs of the Sahel: Their Characteristics and Uses. Germany, Rossdorf: typo-druck-rossdorf gmbh D6101. 
Orwa, C., A. Mutua, Kindt, R , Jamnadass R, S. Anthony. 2009. Agroforestree Database: a tree reference and selection guide version 4.0. Retrieved from (http://www.worldagroforestry.org/sites/treedbs/treedatabases.asp).

Pock Tsy, J-ML, Lumaret R, Mayne D, Vall AOM, Abutaba YIM, Sangna M. et al. 2009. "Chloroplast DNA phylogeography suggests a West African centre of origin for the baobab, Adansonia digitata L. (Bombacoideae, Malvaceae)." Mol Ecol, 18(8):1707-1715.

Sadr, K. 1991. The Development of Nomadism in Ancient Northeast Africa. Philadelphia : University of Pennsylvania Press.

Shinner, J.L. 1971. The Prehistory and Geology of Northern Sudan. Dallas: Report to the National Science Foundation Grant GS 1192. 